\title{
BIOMASS AND NUTRIENT CYCLING BY COVER CROPS IN BRAZILIAN CERRADO IN THE STATE OF PIAUI ${ }^{1}$
}

\author{
LEANDRO PEREIRA PACHECO ${ }^{2}$, MARINETE MARTINS DE SOUSA MONTEIRO ${ }^{3}$, FABIANO ANDRÉ PETTER $^{4}$, \\ JÚLIO CÉSAR AZEVEDO NÓBREGA ${ }^{5}$, ADANIEL SOUSA DOS SANTOS ${ }^{6}$
}

\begin{abstract}
Research on the performance of cover crops in crop systems of annual crops in the Brazilian state of Piauí contributes to increases in yield, greater efficiency of fertilizers and mitigation of environmental impacts. The aim of this study was to evaluate the performance of cover crops in terms of biomass production and the accumulation and release of nutrients during the crop season (November to April) in an oxisol in the Brazilian Cerrado in the state of Piauí that was submitted to different crop production systems including soybeans, maize and upland rice. The experiment was established during the 2010/11 and 2011/12 crop years in the rural area near the municipality of Bom Jesus, Piauí. The experimental design was a randomized block in a split-plot array. Different soil management systems (conventional and no-till) were evaluated in the main plots. Different crop production systems consisting of cover crops sown in the off-season (April to November), and annual crops sown during the crop season (November to April) were implemented in the subplots. The crop production systems that included Urochloa ruziziensis and Pennisetum glaucum overseeded on soybeans and Urochloa ruziziensis simultaneously intercropped with maize stood out in terms of biomass production and the accumulation and release of nutrients. Yields of maize and upland rice declined when sown under newly implemented no-till soil management.
\end{abstract}

Keywords: Brachiaria. Millet. Crotalaria. No-till. Decomposition.

\section{PRODUÇÃO DE FITOMASSA E CICLAGEM DE NUTRIENTES POR PLANTAS DE COBERTURA NO CERRADO PIAUIENSE}

RESUMO - A realização e difusão dos trabalhos referentes ao desempenho de plantas de cobertura em sistemas produtivos de culturas anuais no Piauí são importantes na busca por aumento de produtividade, maior eficiência no uso de fertilizantes e mitigação dos impactos ambientais. O objetivo deste trabalho foi avaliar o desempenho de plantas de cobertura na produção de fitomassa, acúmulo e liberação de nutrientes, durante o período de safra (novembro à abril), em Latossolo Vermelho distrófico no Cerrado piauiense em sistemas de produção com soja, milho e arroz de sequeiro. O experimento foi instalado nas safras agrícola de 2010/11 e 2011/2012 no município de Bom Jesus, PI. O delineamento utilizado foi o de blocos casualizados, em parcelas subdivididas. Nas parcelas estavam os sistemas de manejo do solo (preparo convencional e plantio direto) e nas subparcelas, os sistemas de produção com uso de plantas de cobertura na entressafra intercaladas com culturas anuais. Os sistemas com uso de Urochloa ruziziensis e Pennisetum glaucum semeadas em sobressemeadura na soja e $U$. ruziziensis consorciado de forma simultânea com milho apresentam-se como melhores opções na produção de fitomassa, acúmulo e liberação de nutrientes. As culturas do arroz e milho apresentam redução significativa na produtividade em áreas sob plantio direto recém-implantadas.

Palavras-chave: Braquiária. Milheto. Crotalária. Plantio direto. Decomposição.

\footnotetext{
*Corresponding author

${ }^{1}$ Received for publication in $10 / 10 / 2014$; accepted in $06 / 21 / 2016$

Paper extracted from the masters dissertation of the second author.

${ }^{2}$ Postgraduate Program in Agricultural Engineering, Universidade Federal de Mato Grosso, Rondonópolis, MT, Brazil; leandroppacheco@gmail.com.

${ }^{3}$ Postgraduate Program in Agronomy, Universidade Federal do Piauí, Teresina, PI, Brazil; marinettmartins@hotmail.com.

${ }^{4}$ Postgraduate Program in Agronomy, Universidade Federal de Mato Grosso, Sinop, MT, Brazil; petter@ufmt.br.

${ }^{5}$ Postgraduate Program in Soil Science and Ecosystem Quality, Universidade Federal do Recôncavo Baiano, Cruz das Almas, BA, Brazil; juliocnobrega@gmail.com.

${ }^{6}$ Postgraduate Program in Agronomy, Universidade Federal do Piauí, Bom Jesus, PI, Brazil; adanielssagro@gmail.com.
} 


\section{INTRODUCTION}

The Brazilian state of Piauí has emerged as one of the frontiers of agricultural expansion. In the Crop year 2013/14, the average yield of soybeans and upland rice were 2,990 and $1,907 \mathrm{~kg} \mathrm{ha}^{-1}$, respectively, representing increases of 78.2 and $125.3 \%$ over the previous crop year. For maize, the average yield was $3,189 \mathrm{~kg} \mathrm{ha}^{-1}$, a reduction of $138.5 \%$, as a result of water stress that occurred during this crop year (CONAB, 2013).

The use of inadequate soil management including soil disturbance, absence of cover crops and crop rotation has compromised crop development over the years due to the occurrence of soil erosion and high weed infestation. Technologies such as no-till cropping (SPD) with tilling only in the planting furrow, crop rotation and use of cover crops (MORETI et al., 2007) are important tools that can promote yield gains and quality with less impact to the environment (PACHECO et al., 2013b).

The effectiveness of SPD is related, among other factors, to the amount and quality of crop residues (PIRES et al., 2008). Another relevant factor is the recalcitrance of the residues on the soil surface, which is related to the $\mathrm{C} / \mathrm{N}$ ratio, and other recalcitrant compounds from biomass (CARVALHO et al., 2011). In this system, cover crops contribute to protect the soil from weather agents, sequester atmospheric carbon, increase the soil organic matter, and mobilize and recycle nutrients. Furthermore, considering that frequent dry spells that occur in the agricultural area of the Brazilian Cerrado of Piaui during the development of annual crops, the presence of biomass on the soil surface contributes significantly to increasing the efficiency of water usage (CARVALHO et al., 2011).

The edaphoclimatic conditions (soil and weather) of the Brazilian Cerrado favor the use of grasses as a cover crop, especially millet (Pennisetum glaucum) and Brachiarias (Urochloa sp.), due to the greater tolerance of these species to water stress and their high efficiency of biomass production (LARA CABEZAS et al., 2004). $P$. glaucum stands out for its ability to extract the few nutrients that are available to plants in the soil and to accumulate them in the shoot, which favors nutrient cycling in crop systems, especially nitrogen - N $\left(120 \mathrm{~kg} \mathrm{ha}^{-1}\right)$ and potassium - K (200 $\left.\mathrm{kg} \mathrm{ha}^{-1}\right)$ (CRUSCIOL; SORATTO, 2007).

Cover crops with a perennial habit such as Urochloa spp. present a high potential to produce biomass $\left(8,000 \mathrm{~kg} \mathrm{ha}{ }^{-1}\right)$ and have delayed decomposition compared to P. glaucum (PACHECO et al., 2008). Crotalaria ochroleuca stands out for its resilience under water stress conditions and its high potential to produce biomass. It is used in crop production systems due to its ability favor nutrient cycling in addition to promoting the fixation of atmospheric nitrogen in the soil through symbiotic associations between its roots and native bacteria (BURLE et al., 2006)

Research on the performance of cover crops in crop systems of annual crops in the Brazilian state of Piauí contributes to increases in yield, greater efficiency of fertilizers and mitigation of environmental impacts. Furthermore, this region is considered to be an important Brazilian frontier of agricultural expansion for which studies are essential to measure the effects of cover crops in different soil management systems on biomass production and the accumulation and release of nutrients to the soil.

The aim of this study was to evaluate the performance of cover crops in biomass production and their accumulation and release of nutrients during the crop season (November to April) in oxisols of the Brazilian Cerrado of Piauí submitted to different soil management systems and types of crop production, including soybean, maize and upland rice.

\section{MATERIAL AND METHODS}

The experiment was conducted from November 2010 to April 2012 during the crop years 2010/11 and 2011/12 in the Serra do Quilombo, Celeiro Farm, located in the municipality of Bom Jesus (latitude $9^{\circ} 16^{\prime} 78^{\prime} \mathrm{S}$, longitude $44^{\circ} 44^{\prime} 25^{\prime \prime} \mathrm{W}$ and an altitude of $628 \mathrm{~m}$ ) in the Brazilian state of Piauí. The regional climate is hot and semi-humid (Aw - Köppen) with average temperatures ranging from 18 to $36{ }^{\circ} \mathrm{C}$. The average precipitation and temperatures that occurred during the experiment are presented in Figure 1. The soil is classified as Oxissol and its chemical characteristics and texture are described in Table 1. In terms of the historical use of the area, the soil was cultivated with soybeans during the crop season and Pennisetum glaucum in the off-season under a conventional soil management system for five years.

The experimental design was randomized block in a split-plot array with four replicates. Two soil management systems (conventional and no-till) were implemented in the main plots, and different crop production systems consisting of various combinations of cover crops sown during the off-season (April to November) and annual crops during the crop season (November to April) were evaluated in the subplots during the crop years $2010 / 11$ and 2011/12 as described in Table 2. The dimensions of the subplots were $30 \mathrm{~m}$ wide and $50 \mathrm{~m}$ long. 
Table 1. Chemical and textural characterization of Oxissols under different crop systems with no-tillage and conventional soil management before the implementation of the experiment in crop year 2010/11 in the Brazilian Cerrado of Piauí.

\begin{tabular}{ccccccccccccc}
\hline Soil depth & $\mathrm{pH}$ & $\mathrm{P}$ & $\mathrm{K}^{+}$ & $\mathrm{Ca}^{2+}$ & $\mathrm{Mg}^{2+}$ & $\mathrm{H}+\mathrm{Al}$ & $\mathrm{T}$ & $\mathrm{V}$ & $\mathrm{OM}$ & Sand & Silt & Clay \\
\hline $\mathrm{m}$ & $\mathrm{CaCl}_{2}$ & $-\mathrm{mg} \mathrm{dm}{ }^{-3}-$ & $--------\mathrm{cmol}_{\mathrm{c}} \mathrm{dm}^{-3}----------$ & $\%$ & $\mathrm{~g} \mathrm{dm}^{-3}$ & $-------\mathrm{g} \mathrm{kg}^{-1}------$ & \\
$0.00-0.20$ & 4.9 & 29.6 & 44 & 2.3 & 0.9 & 3.4 & 6.71 & 49 & 14 & 686 & 20 & 294 \\
$0.20-0.40$ & 4.1 & 9.1 & 25 & 1.0 & 0.5 & 3.1 & 4.67 & 34 & 13 & 666 & 40 & 294 \\
\hline
\end{tabular}

$\mathrm{P}=$ available phosphorus; $\mathrm{Ca}^{2+}$ and $\mathrm{Mg}^{2+}=$ exchangeable; $\mathrm{H}+\mathrm{Al}=$ potential acidity; $\mathrm{T}=$ cation exchange capacity at $\mathrm{pH}$ $7.0 ; \mathrm{V}=$ base saturation; $\mathrm{OM}=$ organic matter.

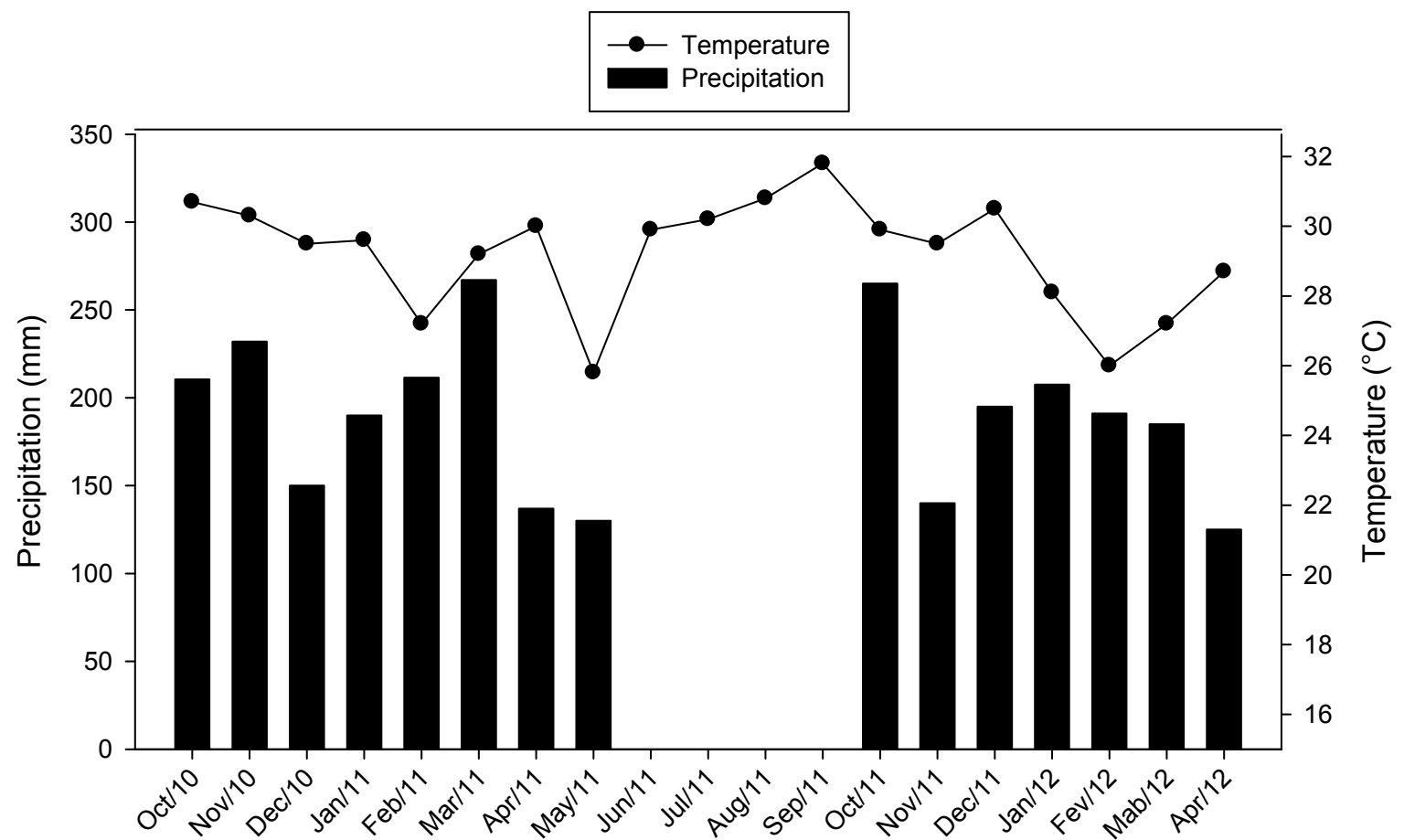

Figure 1. Precipitation and average temperatures over the course of the experiment in the Brazilian Cerrado in the State of Piauí.

In treatments $\mathrm{S}_{3}$ and $\mathrm{S}_{4}$, the overseeding of cover crops was performed by throw sowing when soybeans were in the full flowering stage $-\mathrm{R}_{5.5}(80 \%$ of grain filling). In the $\mathrm{S}_{2}$ treatment, the cover crops were sown in the second season $\left(\mathrm{S}_{2}\right)$ immediately after the annual crop harvest, which occurred on April 16, 2011. The seedling P. glaucum $\left(\mathrm{S}_{3}\right)$ was performed in the pre-season, 45 days before soybean sowing. In the $\mathrm{S}_{5}$ treatment (simultaneous consortium between maize and U. ruziziensis), the seeds of $U$. ruziziensis were mixed with the fertilizers used in the planting rows.

The treatments under the conventional soil management system were subjected to disking twice (disc harrow + leveling) 45 days before the sowing of annual crops. For the treatments under no-tillage, desiccation was carried out 20 days before the sowing of annual crops using glyphosate (1440 g.i.a ha ${ }^{-1}$ ). The soybean cultivars used were MSOY 9144 RR $^{\circledR}$ (Crop year 2010/11, 12 December 2010) and MSOY 8766 RR $^{\circledR}$ (Crop year 2011/12, 10 December 2011) with a row spacing of $0.50 \mathrm{~m}$ and a plant stand of 12 plants $\mathrm{m}^{-1}$. For maize, the hybrids PIONEER 30A04 (Crop year 2010/11, 19 December
2010 ) and SYNGENTA STATUS $7205^{\circledR}$ (Crop year 2011/12, 17 December 2011) were used with a row spacing of $0.50 \mathrm{~m}$ and a stand of 3.0 plants $\mathrm{m}^{-1}$. For upland rice, the cultivar BRS sertaneja ${ }^{\circledR}$ (crop year $2011 / 12$, December 12, 2010) was used with a row spacing of $0.50 \mathrm{~m}$ and a stand of 85 plants $\mathrm{m}^{-1}$.

The fertilization used in the row sowing of soybean (Crop year 2010/11) was $500 \mathrm{~kg} \mathrm{ha}^{-1}$ formulated fertilizer N-P-K $(00: 20: 18)$ with the addition of $50 \mathrm{~kg} \mathrm{ha}^{-1}$ of $\mathrm{K}_{2} \mathrm{O}$ (source fertilizer potassium chloride) applied up to 30 days after soybean sowing. For maize, $500 \mathrm{~kg} \mathrm{ha}^{-1}$ formulated fertilizer N-P-K (08:20:20) was used in the row sowing and $100 \mathrm{~kg} \mathrm{ha}^{-1}$ of nitrogen $(\mathrm{N})$ was used as a source of urea when the plants exhibited three fully expanded leaves. In the crop year 2011/12, the fertilization used for the seedlings (row sowing) of all annual crops was $500 \mathrm{~kg} \mathrm{ha}^{-1}$ of formulated fertilizer (03:31:07), adding $100 \mathrm{~kg} \mathrm{ha}^{-1}$ and $75 \mathrm{~kg} \mathrm{ha}^{-1}$ of nitrogen as a source of urea for maize and upland rice, respectively. For soybean and maize, $120 \mathrm{~kg} \mathrm{ha}^{-1}$ of $\mathrm{K}_{2} \mathrm{O}$ was applied to the soil surface and $40 \mathrm{~kg} \mathrm{ha}^{-1}$ of $\mathrm{K}_{2} \mathrm{O}$ was used for upland rice 20 days after sowing. 
Table 2. Treatment characterization of the subplots under different crop systems with no-tillage and conventional soil management in the Brazilian Cerrado of Piauí during the pre-season and crop season of 2010/11 and the off-season, pre-season and crop season of 2011/12.

\begin{tabular}{|c|c|c|c|c|c|}
\hline Crop systems & $\begin{array}{l}\text { Pre-season } \\
(\text { Oct } / 2010)\end{array}$ & $\begin{array}{l}\text { Crop season } 2010 / 2011 \\
\text { (Dec/2010 to Apr/2011) }\end{array}$ & $\begin{array}{l}\text { Off-season } \\
\text { (Apr/2011 to } \\
\text { Nov/2011) }\end{array}$ & $\begin{array}{l}\text { Pre-season } \\
(\text { Oct/2011) }\end{array}$ & $\begin{array}{c}\text { Crop season } \\
2011 / 12 \\
\text { (Nov/2011 to } \\
\text { Apr/2012) } \\
\end{array}$ \\
\hline S1 & -- & Soybean & Pousio & -- & Soybean \\
\hline S2 & -- & Soybean & $\begin{array}{l}\text { P. } \text { glaucum }^{(1)} \\
\text { ADR300 }^{(1)}\end{array}$ & $\begin{array}{l}\text { C. ochroleuca } \\
\left(25 \mathrm{~kg} \mathrm{ha}^{-1}\right)^{(1)}\end{array}$ & Upland rice \\
\hline S3 & $\begin{array}{l}\text { P. glaucum } \\
\text { ADR300-20 } \\
\text { kg ha }^{-1(1)}\end{array}$ & $\begin{array}{l}\text { Soybean }+ \text { overseed } U . \\
\text { ruziziensis - } 13 \mathrm{~kg} \mathrm{ha}^{-1} \text {, } \\
\text { Cultural value: } 60^{(2)}\end{array}$ & $\begin{array}{c}U . \\
\text { ruziziensis }\end{array}$ & -- & Soybean \\
\hline S4 & -- & $\begin{array}{l}\text { Soybean + overseed } P \text {. } \\
\text { glaucum ADR300 - } 25 \mathrm{~kg} \\
\text { ha }^{-1}\end{array}$ & $\begin{array}{l}\text { P. glaucum } \\
\text { ADR300 }\end{array}$ & -- & $\begin{array}{l}\text { Maize }+U . \\
\text { ruziziensis }\end{array}$ \\
\hline S5 & -- & $\begin{array}{l}\text { Maize }+ \text { U. ruziziensis } \\
\left(10 \mathrm{~kg} \mathrm{ha}^{-1}, \mathrm{CV}: 60\right)\end{array}$ & $\begin{array}{c}U . \\
\text { ruziziensis }\end{array}$ & -- & $\begin{array}{l}\text { Maize }+U \\
\text { ruziziensis }\end{array}$ \\
\hline
\end{tabular}

${ }^{(1)}=$ Throw sowing. ${ }^{(2)}=$ overseeding of cover crops performed when soybean was in the full flowering stage $-\mathrm{R}_{5.5}(80 \%$ of grain filling).

The measurement of biomass and the rate of soil coverage by cover crops commenced on the day of desiccation that preceded the sowing the annual crops in the crop year 2011/12, on 22 November 2011, and was repeated 15, 30, 60, 95 and 130 days after desiccation (DAD). These measurements were performed only in the subplots submitted to no-tillage following the methodology described by Crusciol et al. (2005), in which plant residues were collected at four replicate locations per subplot and were used to quantify biomass and its concentrations of $\mathrm{N}, \mathrm{P}, \mathrm{K}, \mathrm{Ca}, \mathrm{Mg}, \mathrm{C}$, lignin, cellulose and hemicellulose through the methodologies proposed by Nogueira et al. (2005) and Van Soest et al. (1991). The rate of soil coverage was measured using an iron square with the dimensions of $0.5 \mathrm{~m}$ on each side $\left(0.25 \mathrm{~m}^{2}\right)$ with 9 nylon cords spaced every $5 \mathrm{~cm}$ arranged in both directions to form 81 intersections, noting the presence or absence of plant residues at each of these points (SODRÉ FILHO et al., 2004).

To develop the equations describing the decomposition of biomass and the release of nutrients, the data collected at $0,15,30,60,95$ and 130 DAD were adjusted using an exponential mathematical model described by Wieder and Lang (1982): $\mathrm{P}_{\mathrm{L}}=\mathrm{Co}+\mathrm{Po} \exp (-\mathrm{kt})$, in which $\mathrm{P}_{\mathrm{L}}$ is the amount of biomass and nutrients at time $\mathrm{t}\left(\mathrm{kg} \mathrm{ha}^{-1}\right)$, Co is a constant of the equation, Po is the fraction of biomass or nutrients potentially released $\left(\mathrm{kg} \mathrm{ha}^{-1}\right)$, and $\mathrm{k}$ is the rate of biomass decomposition or release of nutrients to the soil $\left(\mathrm{g} \mathrm{g}^{-1}\right)$. The $\mathrm{k}$ value is used to calculate the half-life $\left(\mathrm{T}^{1 / 2}\right.$ life) of the biomass and nutrients remaining through of the use of the following formula: $\mathrm{T}^{1} / 2$ life $=0.693 / \mathrm{k}$, which was described by Paul and Clark (1989). These parameters were quantified based on the crop yield in the crop year 2011/12 through the grain harvested in $5 \mathrm{~m}^{-2}$ of the central area of each subplot.

The data were submitted to analysis of variance, and the means of the qualitative data were compared by Tukey test at $5 \%$ probability. For quantitative data, the mathematical models (regression equations) were obtained using Sigma Plot $\AA$ software, version 10.1 .

\section{RESULTS AND DISCUSSION}

The analysis of variance showed that for biomass (FS) and the rate of soil coverage (TCS), there was a significant interaction among the soil management systems and the crop systems (Table 3 ). At the moment of desiccation (0DAD), the treatments submitted to SPD allowed a significant presence of biomass on the soil surface, which resulted in high TCS. Crop systems that used overseeding of soybean with $U$. ruziziensis $\left(\mathrm{S}_{3}\right)$ and P. glaucum $\left(\mathrm{S}_{4}\right)$ and that involved $U$. ruziziensis intercropped with maize $\left(\mathrm{S}_{5}\right)$ were the most promising, attested by values of FS ranging from $10,800 \mathrm{~kg} \mathrm{ha}^{-1}$ to $12,700 \mathrm{~kg} \mathrm{ha}^{-1}$ and $100 \%$ TCS. Adding biomass of the plant residues derived from the harvest of soybeans $\left(5,500 \mathrm{~kg} \mathrm{ha}^{-1}\right)$ and maize $\left(7,000 \mathrm{~kg} \mathrm{ha}^{-1}\right)$, the annual amount of FS in these systems reached $18000 \mathrm{~kg} \mathrm{ha}^{-1}$, which is sufficient to 
meet the demands of biomass in no-tillage systems of the Brazilian Cerrado in the state of Piauí. Pacheco et al. (2013b) noted that $6,000 \mathrm{~kg} \mathrm{ha}^{-1}$ of biomass derived from cover crops sown in succession with soybeans resulted in $100 \%$ TCS.

Table 3. Biomass $\left(\mathrm{kg} \mathrm{ha}^{-1}\right)$ and the rate of soil coverage (\%) by cover crops in different soil management and crop systems during the crop year 2011/12, Bom Jesus, PI.

\begin{tabular}{|c|c|c|c|c|c|c|}
\hline \multirow{3}{*}{ Crop systems ${ }^{(2)}$} & \multicolumn{6}{|c|}{ Biomass $\left(\mathrm{kg} \mathrm{ha}^{-1}\right)$} \\
\hline & \multicolumn{2}{|c|}{$0 \mathrm{DAD}$} & \multicolumn{2}{|c|}{$15 \mathrm{DAD}$} & \multicolumn{2}{|c|}{$30 \mathrm{DAD}$} \\
\hline & $\mathrm{SPC}^{(3)}$ & $\mathrm{SPD}^{(3)}$ & SPC & SPD & SPC & SPD \\
\hline S1 & $0.0 \mathrm{Ba}$ & $4529.3 \mathrm{Ac}$ & $0.0 \mathrm{Ba}$ & 3174.2Ac & $0.0 \mathrm{Ba}$ & $2434.3 \mathrm{Ad}$ \\
\hline S2 & $0.0 \mathrm{Ba}$ & $4658.2 \mathrm{Ac}$ & $0.0 \mathrm{Ba}$ & $2940.0 \mathrm{Ac}$ & $0.0 \mathrm{Ba}$ & 1991.7Ad \\
\hline S3 & $0.0 \mathrm{Ba}$ & $10842.1 \mathrm{Ab}$ & $0.0 \mathrm{Ba}$ & 7296.4Aa & $0.0 \mathrm{Ba}$ & 5950.9Aa \\
\hline S4 & $0.0 \mathrm{Ba}$ & $12743.3 \mathrm{Aa}$ & $0.0 \mathrm{Ba}$ & $5633.0 \mathrm{Ab}$ & $0.0 \mathrm{Ba}$ & $4802.1 \mathrm{Ab}$ \\
\hline S5 & $0.0 \mathrm{Ba}$ & $11193.0 \mathrm{Ab}$ & $0.0 \mathrm{Ba}$ & $5756.4 \mathrm{Ab}$ & $0.0 \mathrm{Ba}$ & 4287.1Ac \\
\hline CV (\%) & \multicolumn{2}{|c|}{6.63} & \multicolumn{2}{|c|}{13.42} & \multicolumn{2}{|c|}{12.09} \\
\hline \multirow[t]{2}{*}{ DMS } & \multicolumn{2}{|c|}{597.61} & \multicolumn{2}{|c|}{682.86} & \multicolumn{2}{|c|}{482.84} \\
\hline & \multicolumn{2}{|c|}{$60 \mathrm{DAD}$} & \multicolumn{2}{|c|}{$95 \mathrm{DAD}$} & \multicolumn{2}{|c|}{$130 \mathrm{DAD}$} \\
\hline S1 & $0.0 \mathrm{Ba}$ & 2096.8Ac & $321.8 \mathrm{Bb}$ & $1359.4 \mathrm{Ac}$ & 846.1Bd & $2566.0 \mathrm{Ac}$ \\
\hline S2 & $0.0 \mathrm{Ba}$ & 1355.8Ad & $364.9 \mathrm{Bb}$ & 719.9Ad & $2357.2 \mathrm{Bb}$ & 3089.7Ac \\
\hline S3 & $0.0 \mathrm{Ba}$ & $5170.0 \mathrm{Aa}$ & $1356.1 \mathrm{Ba}$ & 4139.1Aa & $1633.4 \mathrm{Bc}$ & $4072.1 \mathrm{Ab}$ \\
\hline S4 & $0.0 \mathrm{Ba}$ & $4212.0 \mathrm{Ab}$ & $452.3 \mathrm{Bb}$ & $3472.0 \mathrm{Ab}$ & $3086.0 \mathrm{Ba}$ & $5668.3 \mathrm{Aa}$ \\
\hline S5 & $0.0 \mathrm{Ba}$ & $3998.6 \mathrm{Ab}$ & $594.3 \mathrm{Bb}$ & $3460.1 \mathrm{Ab}$ & $3600.5 \mathrm{Ba}$ & $5211.0 \mathrm{Aa}$ \\
\hline CV (\%) & \multicolumn{2}{|c|}{14.71} & \multicolumn{2}{|c|}{13.08} & \multicolumn{2}{|c|}{10.9} \\
\hline \multirow[t]{4}{*}{ DMS } & \multicolumn{2}{|c|}{508.16} & \multicolumn{2}{|c|}{435.83} & \multicolumn{2}{|c|}{718.79} \\
\hline & \multicolumn{6}{|c|}{ Rate of soil coverage (\%) } \\
\hline & \multicolumn{2}{|c|}{$0 \mathrm{DAD}$} & \multicolumn{2}{|c|}{$15 \mathrm{DAD}$} & \multicolumn{2}{|c|}{$30 \mathrm{DAD}$} \\
\hline & SPC & SPD & SPC & SPD & SPC & SPD \\
\hline S1 & $0.00 \mathrm{Ba}$ & $87.50 \mathrm{Ab}$ & $0.00 \mathrm{Ba}$ & $85.83 \mathrm{Abc}$ & $0.00 \mathrm{Ba}$ & 74.17Ac \\
\hline S2 & $0.00 \mathrm{Ba}$ & $86.67 \mathrm{Ab}$ & $0.00 \mathrm{Ba}$ & 81.67Ac & $0.00 \mathrm{Ba}$ & $79.17 \mathrm{Ab}$ \\
\hline S3 & $0.00 \mathrm{Ba}$ & $100.00 \mathrm{Aa}$ & $0.00 \mathrm{Ba}$ & $98.17 \mathrm{Aa}$ & $0.00 \mathrm{Ba}$ & $91.67 \mathrm{Aa}$ \\
\hline S4 & $0.00 \mathrm{Ba}$ & $100.00 \mathrm{Aa}$ & $0.00 \mathrm{Ba}$ & $86.50 \mathrm{Abc}$ & $0.00 \mathrm{Ba}$ & $80.67 \mathrm{Ab}$ \\
\hline S5 & $0.00 \mathrm{Ba}$ & $100.00 \mathrm{Aa}$ & $0.00 \mathrm{Ba}$ & $91.33 \mathrm{Ab}$ & $0.00 \mathrm{Ba}$ & $87.5 \mathrm{Aa}$ \\
\hline $\mathrm{CV}(\%)$ & \multicolumn{2}{|c|}{4.58} & \multicolumn{2}{|c|}{7.45} & & \\
\hline \multirow[t]{2}{*}{ DMS } & & & & & & \\
\hline & & $\mathrm{AD}$ & & & & \\
\hline S1 & $0.00 \mathrm{Ba}$ & $64.1 \mathrm{Ac}$ & $51.6 \mathrm{Ba}$ & $65.0 \mathrm{Ac}$ & 69.1Aa & $72.2 \mathrm{Ab}$ \\
\hline S2 & $0.00 \mathrm{Ba}$ & $62.5 \mathrm{Ac}$ & $52.5 \mathrm{Aa}$ & 53.3Ad & $64.7 \mathrm{Aa}$ & $62.0 \mathrm{Ac}$ \\
\hline S3 & $0.00 \mathrm{Ba}$ & $90.1 \mathrm{Aa}$ & $50.8 \mathrm{Ba}$ & 85.0Aa & $66.5 \mathrm{Ba}$ & $91.6 \mathrm{Aa}$ \\
\hline S4 & $0.00 \mathrm{Ba}$ & $77.5 \mathrm{Ab}$ & $30.8 \mathrm{Bb}$ & $75.8 \mathrm{Ab}$ & $67.5 \mathrm{Ba}$ & $79.5 \mathrm{Ab}$ \\
\hline
\end{tabular}

Means followed by the same letters in columns bounded by the upper and lower lines do not differ based on Tukey's test at $5 \%$ probability. ${ }^{(1)}$ DAD: days after desiccation. ${ }^{(2)} \mathbf{S}_{\mathbf{1}^{-}}$- Soybean monoculture (crop years 2010/11 and 2011/12); $\mathbf{S}_{\mathbf{2}}-$ Soybean in crop season and millet $\left(20 \mathrm{~kg} \mathrm{ha}^{-1}\right)$ in the off-season (crop year 2010/11), Crotalaria in the pre-season before sowing upland rice (crop year 2011/12); $\mathbf{S}_{3}$-Millet in pre-season before sowing soybean and overseeded U. ruziziensis (13 kg ha ${ }^{-1}, \mathrm{VC}: 60$ ) on soybean at the phenological stage $\mathrm{R}_{5.6}$ (crop years 2010/11 and 2011/12); $\mathbf{S}_{\mathbf{4}}$ - Soybean in the crop season and overseeded millet on soybean at the phenological stage $\mathrm{R}_{5.6}\left(25 \mathrm{~kg} \mathrm{ha}^{-1}\right)$ (crop year 2010/11); $\mathbf{S}_{5}$ - Maize in the crop season intercropped with $U$. ruziziensis (crop year 2011/12). ${ }^{(3)}$ SPC and SPD: conventional and no-tillage soil management systems. 
Table 3. Continuation.

\begin{tabular}{|c|c|c|c|c|c|c|}
\hline \multirow{3}{*}{ Crop systems ${ }^{(2)}$} & \multicolumn{6}{|c|}{ Biomass $\left(\mathrm{kg} \mathrm{ha}^{-1}\right)$} \\
\hline & \multicolumn{2}{|c|}{$0 \mathrm{DAD}$} & \multicolumn{2}{|c|}{$15 \mathrm{DAD}$} & \multicolumn{2}{|c|}{$30 \mathrm{DAD}$} \\
\hline & $\mathrm{SPC}^{(3)}$ & $\mathrm{SPD}^{(3)}$ & $\mathrm{SPC}$ & SPD & $\mathrm{SPC}$ & SPD \\
\hline & \multicolumn{2}{|c|}{$60 \mathrm{DAD}$} & \multicolumn{2}{|c|}{95 DAD } & \multicolumn{2}{|c|}{$130 \mathrm{DAD}$} \\
\hline S5 & $0.00 \mathrm{Ba}$ & $80.8 \mathrm{Ab}$ & $35.0 \mathrm{Bb}$ & 79.1Aab & $68.3 \mathrm{Ba}$ & $90.0 \mathrm{Aa}$ \\
\hline CV (\%) & \multicolumn{2}{|c|}{7.3} & \multicolumn{2}{|c|}{5.1} & \multicolumn{2}{|c|}{6.1} \\
\hline DMS & \multicolumn{2}{|c|}{5.6} & \multicolumn{2}{|c|}{6.0} & \multicolumn{2}{|c|}{9.2} \\
\hline
\end{tabular}

Means followed by the same letters in columns bounded by the upper and lower lines do not differ based on Tukey's test at 5\% probability. ${ }^{(1)}$ DAD: days after desiccation. ${ }^{(2)} \mathbf{S}_{1^{-}}$- Soybean monoculture (crop years 2010/11 and 2011/12); $\mathbf{S}_{\mathbf{2}}$ - Soybean in crop season and millet $\left(20 \mathrm{~kg} \mathrm{ha}^{-1}\right)$ in the off-season (crop year 2010/11), Crotalaria in the pre-season before sowing upland rice (crop year 2011/12); $\mathbf{S}_{3}$-Millet in pre-season before sowing soybean and overseeded $U$. ruziziensis (13 $\mathrm{kg} \mathrm{ha}^{-1}$, VC:60) on soybean at the phenological stage $\mathrm{R}_{5.6}$ (crop years 2010/11 and 2011/12); $\mathbf{S}_{4}$ - Soybean in the crop season and overseeded millet on soybean at the phenological stage $\mathrm{R}_{5.6}\left(25 \mathrm{~kg} \mathrm{ha}^{-1}\right)$ (crop year 2010/11); $\mathbf{S}_{\mathbf{5}}$ - Maize in the crop season intercropped with $U$. ruziziensis (crop year 2011/12). ${ }^{(3)}$ SPC and SPD: conventional and no-tillage soil management systems.

Satisfactory results regarding the overseeding of $U$. ruziziensis and P. glaucum on soybean in the Brazilian Cerrado resulted in the accumulation of FS (9000 kg ha $\mathrm{kg}^{-1}$ and $5500 \mathrm{~kg} \mathrm{ha}^{-1}$, respectively) and a TCS close to $100 \%$ at the end of the off-season (October) (PACHECO et al., 2008). However, over the course of the experiment there was significant precipitation after the overseeding of cover crops occurred, resulting in the proper development of seedlings. Carvalho et al. (2011) also highlighted the use of $U$. ruziziensis in maize production systems for the purpose of the use of livestock due to high FS $\left(9000 \mathrm{~kg} \mathrm{ha}^{-1}\right)$ in the area of the Brazilian Cerrado in Planaltina (DF).

After the desiccation of cover crops in SPD, the decomposition of plant residues began. The regression equations for all crop systems decreased exponentially, showing that the decomposition of FS occurred in two stages: an initial high rate of decomposition followed by another stage in which the rate of decomposition stabilized (Figure 2). We observed that the systems using overseeding of $P$. glaucum on soybeans $\left(\mathrm{S}_{4}\right)$ and $U$. ruziziensis intercropped with maize $\left(\mathrm{S}_{5}\right)$ showed higher rates of decomposition, confirmed by the lower half-life time of decomposition (5.4 and 6.7 days, Table 4). These results are explained due to the lower concentrations of lignin and cellulose in the plant tissues at the time of desiccation of the cover crops (Table 4) and the high average temperatures and precipitation that occurred during the decomposition of biomass (Figure 1). Carvalho et al. (2011) highlighted that cover crops with lower concentrations of lignin in biomass showed higher rates of decomposition.

There was significant emergence of seedlings of $P$. Glaucum originating from seeds produced during the off-season. For U. ruziziensis, high regrowth occurred with precipitation in October 2011 (beginning of the crop season). These results explain the presence of young tissues in biomass, which resulted in lower contents of recalcitrant compounds (lignin and cellulose) as reported in previous studies (GIACOMINI et al., 2003; AITA; GIACOMINI, 2003).

The half-life time ( $\mathrm{T}_{1 / 2}$ life) of biomass in the Brazilian Cerrado in the State of Piauí was lower (5.4 to 15.4 days) compared to results obtained from other areas in the Brazilian Cerrado. A previous study conducted in the Brazilian Cerrado in the State of Goiás found the $\mathrm{T}_{1 / 2}$ life of $U$. ruziziensis to be 42 days and that of P. Glaucum to be 63 days. These results were attributed to the occurrence of lower average temperatures during the crop season in the State of Goiás (October to April), which reduced the activity of biomass decomposing agents.

$U$. ruziziensis overseeded on soybean $\left(\mathrm{S}_{3}\right)$ showed the highest potential to accumulate nutrients $(\mathrm{N}, \mathrm{P}, \mathrm{K}, \mathrm{Ca}$ and $\mathrm{Mg}$ ) in its biomass at the end of the off-season (Figure 3). These results are correlated with the high production of biomass on the soil surface of this species due to its high tolerance of hydrological stress and its ability to regrow after the beginning of precipitation. It has been reported that $U$. ruziziensis and P. glaucum sown in the Brazilian Cerrado in the State of Goiás showed lower accumulations of $\mathrm{N}, \mathrm{P}, \mathrm{K}, \mathrm{Ca}$ and $\mathrm{Mg}(116.1,10.4$, 92.9 and $11.6 \mathrm{~kg} \mathrm{ha}{ }^{-1}$, respectively, for $U$. ruziziensis) and (28.3, 2.6, 12.8 and $3.9 \mathrm{~kg} \mathrm{ha}^{-1}$, respectively, for $P$. glaucum) (PACHECO et al., 2011). Other studies (Torres et al., 2008) conducted in the Brazilian Cerrado in the State of Minas Gerais showed that $U$. ruziziensis accumulated lower biomass $\left(53 \mathrm{~kg} \mathrm{ha}^{-1}\right)$ compared to that observed in our study. The plants of $U$. ruziziensis intercropped with maize $\left(\mathrm{S}_{5}\right)$ were more developed compared to those overseeded on soybean $\left(\mathrm{S}_{3}\right)$ at the beginning of off-season. However, the presence of the plant residues of maize reduced the development of $U$. ruziziensis during the off-season, which resulted in similar values of biomass at the end of the off-season in both crop systems. 

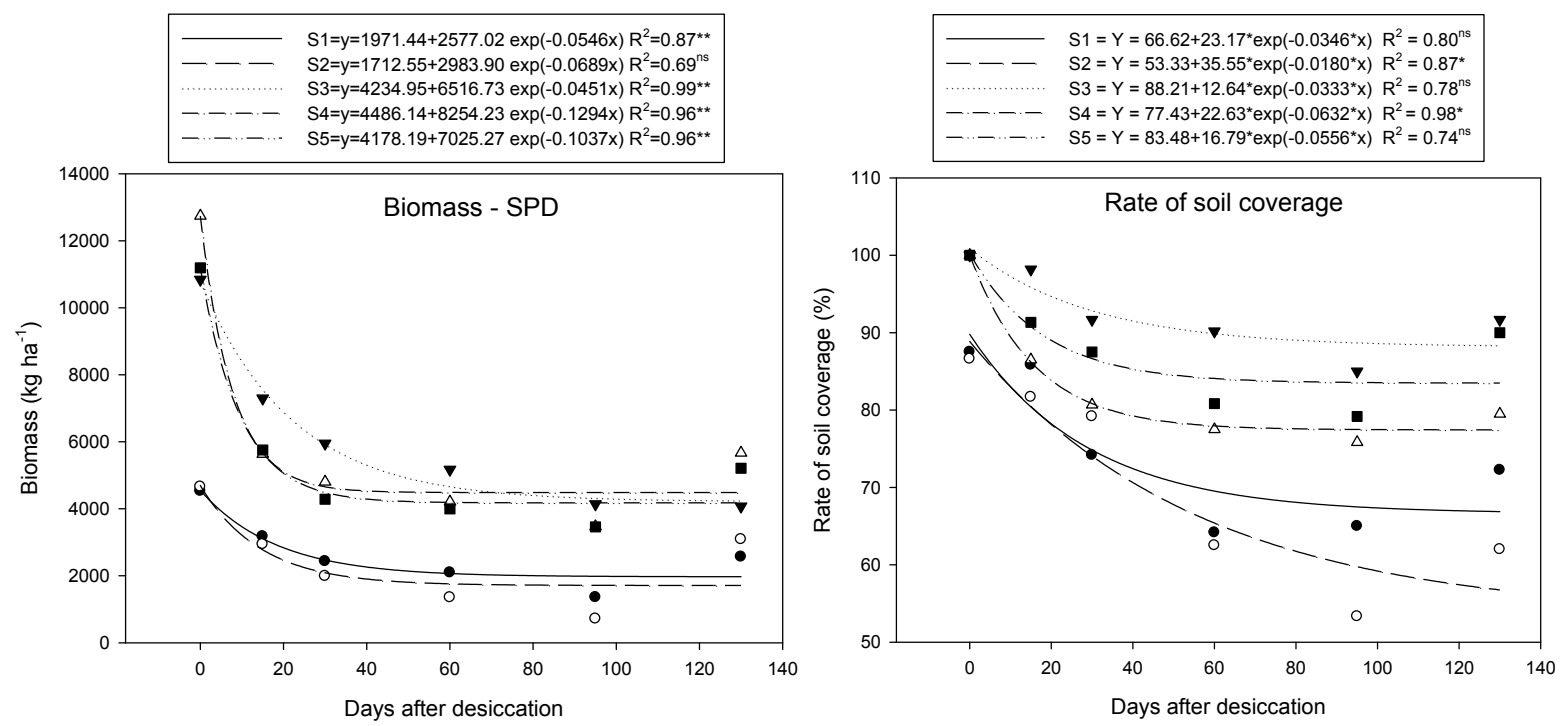

Figure 2. Biomass $\left(\mathrm{kg} \mathrm{ha}^{-1}\right)$ and rate of decomposition (\%) in the crop systems under no-tillage (SPD) during the Crop year 2011/12 in the municipality of Bom Jesus, PI.

Table 4. Half-life time of biomass and nutrients, $\mathrm{C} / \mathrm{N}$ ratio, and cellulose, hemicellulose and lignin contents in the biomass on the soil surface in the crop systems during Crop year 2011/12 in the municipality of Bom Jesus, PI.

\begin{tabular}{|c|c|c|c|c|c|c|c|c|c|c|}
\hline Crop Systems ${ }^{1}$ & $\mathrm{FS}^{2}$ & $\mathrm{~N}$ & $\mathrm{P}$ & $\mathrm{K}$ & $\mathrm{Ca}$ & $\mathrm{Mg}$ & $\mathrm{C} / \mathrm{N}^{2}$ & $\mathrm{CEL}^{2}$ & $\mathrm{HEM}^{2}$ & $\mathrm{LIG}^{2}$ \\
\hline & \multicolumn{6}{|c|}{ Half-life time - $\mathrm{T}_{1 / 2}$ (days) } & \multicolumn{4}{|c|}{$\%$} \\
\hline S1 & 12.7 & 3.9 & 11.6 & 15.9 & 8.7 & 13.5 & 46 & 45.15 & 22.61 & 11.79 \\
\hline S2 & 10.1 & 3.9 & 8.2 & 10.9 & 12.3 & 19.5 & 74 & 54.41 & 23.92 & 11.24 \\
\hline S3 & 15.4 & 6.7 & 38.3 & 12.3 & 48.2 & 2.0 & 32 & 20.97 & 22.41 & 6.97 \\
\hline S4 & 5.4 & 4.1 & 17.1 & 6.7 & 5.5 & 3.7 & 59 & 33.66 & 23.89 & 4.21 \\
\hline S5 & 6.7 & 5.8 & 14.5 & 5.3 & 20.0 & 10.4 & 48 & 31.68 & 23.87 & 4.25 \\
\hline
\end{tabular}

${ }^{(1)} \mathbf{S}_{\mathbf{1}^{-}}$Soybean monoculture (Crop years 2010/11 and 2011/12); $\mathbf{S}_{\mathbf{2}}$ - Soybean in crop season and millet $\left(20 \mathrm{~kg} \mathrm{ha}^{-1}\right)$ in the off-season (crop year 2010/11), Crotalaria in the pre-season before sowing upland rice (Crop year 2011/12); $\mathbf{S}_{\mathbf{3}}$-Millet in the pre-season before sowing soybean and overseeded U. ruziziensis (13 $\left.\mathrm{kg} \mathrm{ha}^{-1}, \mathrm{VC}: 60\right)$ on soybean at the phenological stage $\mathrm{R}_{5.6}$ (Crop years 2010/11 and 2011/12); $\mathbf{S}_{4}$ - Soybean in the crop season and overseeded millet on soybean at the phenological stage $\mathrm{R}_{5.6}\left(25 \mathrm{~kg} \mathrm{ha}^{-1}\right.$ ) (crop year 2010/11); $\mathbf{S}_{5}$ - Maize in the crop season intercropped with U. ruziziensis (Crop year 2011/12). ${ }^{(2)} \mathrm{FS}=$ biomass; $\mathrm{C}=$ carbon; $\mathrm{N}=$ nitrogen; $\mathrm{CEL}=$ cellulose; $\mathrm{HEM}=$ hemicellulose; $\mathrm{LIG}=$ lignin.

Crop systems that included $P$. glaucum overseeded on soybean $\left(\mathrm{S}_{4}\right)$ showed satisfactory results in the accumulation of nutrients in its biomass at the end of the off-season, especially for $\mathrm{K}$ $\left(155 \mathrm{~kg} \mathrm{ha}^{-1}\right)$. Similar results have been reported by other studies (PACHECO et al., 2011; PACHECO et al., 2013a), in which P. glaucum accumulated $\mathrm{K}$ in the amounts of between 53 and $115 \mathrm{~kg} \mathrm{ha}^{-1}$. Several factors can influence the performance of $P$. glaucum in accumulating nutrients in its biomass during the off-season, such as the edaphoclimatic conditions of particular regions and crop years, soil fertility, cultivar identity and time of desiccation (early or late).

Regression analysis of the release of nutrients in SPD (exponential decay) showed that the release occurred in two stages: a faster initial phase followed by a slower phase (Figure 3). This mathematical equation is already used by several authors in studies addressing the release of nutrients that have accumulated in the biomass of cover crops (BORGHI et al., 2006; PACHECO et al., 2010). Nitrogen showed the highest rate of release to the soil, followed by $\mathrm{Mg}, \mathrm{K}, \mathrm{P}$ and $\mathrm{Ca}$. These results were similar to those found in other studies conducted in the Brazilian Cerrado (PACHECO et al., 2011). The rates of nutrient release observed in the Brazilian Cerrado in the state of Piauí were higher when compared to those found in studies conducted in other regions of the Brazilian Cerrado (PACHECO et al., 2011), attested by $\mathrm{T}_{1 / 2}$ lives of under 20 days for all nutrients analyzed (Table 4). These reports are attributed to higher temperatures and significant precipitation that occurred in the state 
of Piauí after the desiccation of the cover crops and the sowing of the annual crops. These factors can contribute to high activities of microorganisms associated with the decomposition of biomass and the release of nutrients. Carneiro et al. (2009) showed that the use of SPD increased biological soil attributes in the Brazilian Cerrado in the State of Mato Grosso do Sul and that temperature was one of the factors that most influenced the results.

The $\mathrm{C} / \mathrm{N}$ ratio is considered to be a major parameter explaining the rate of decomposition and the release of nutrients. However, in the current study, there was no proportionality found between the $\mathrm{C} / \mathrm{N}$ ratio and the rate of biomass decomposition (Table 4). These results are consistent with those found by Pacheco et al. (2011). Lignin content was found to be the parameter that best explained the rate of decomposition (Table 4).

The grain yields of soybeans, upland rice and maize showed significant effects of the different soil management systems varying in the use of crop systems (Table 5). The highest grain yields were observed under SPC, in which soil disturbance favored the initial development of seedlings. These results are attributed to increases in of the soil aeration (KLUTHCOUSKI et al., 2000), the lower presence of allelopathic substances (PACHECO et al., 2009) and the higher nutrient availability in the early phenological stages of annual crops (BERTIN et al., 2005).

Soybeans sown in succession with $U$. ruziziensis $\left(\mathrm{S}_{3}\right)$ under recently implemented SPD resulted in an increase in yield compared to the fallow plots (S1). These results are related to their high accumulation and release of biomass and nutrients, which confirms the importance of cover crops in the early years of SPD. The crop systems in which maize was sown $\left(\mathrm{S}_{4}\right.$ and $\left.\mathrm{S}_{5}\right)$ showed similar yields. However, when maize was sown under SPD, there was a reduction in yield compared to SPC. These results suggest that maize should not be sown in soils under recently implemented SPD. For upland rice, the soil disturbance caused by conventional tillage favored grain yield due to the incorporation of plant residues increasing soil aeration (root growth), which favored the mineralization of organic matter and increased the available nitrogen $\left(\mathrm{NO}_{3}{ }^{-}\right.$and $\mathrm{NH}_{4}{ }^{+}$).

The $\mathrm{C} / \mathrm{N}$ ratio is considered to be a major parameter explaining the rate of decomposition and the release of nutrients. However, in the current study, there was no proportionality found between the $\mathrm{C} / \mathrm{N}$ ratio and the rate of biomass decomposition (Table 4). These results are consistent with those found by Pacheco et al. (2011). Lignin content was found to be the parameter that best explained the rate of decomposition (Table 4).

The grain yields of soybeans, upland rice and maize showed significant effects of the different soil management systems varying in the use of crop systems (Table 5). The highest grain yields were observed under SPC, in which soil disturbance favored the initial development of seedlings. These results are attributed to increases in of the soil aeration (KLUTHCOUSKI et al., 2000), the lower presence of allelopathic substances (PACHECO et al., 2009) and the higher nutrient availability in the early phenological stages of annual crops (BERTIN et al., 2005).

Soybeans sown in succession with $U$. ruziziensis $\left(\mathrm{S}_{3}\right)$ under recently implemented SPD resulted in an increase in yield compared to the fallow plots (S1). These results are related to their high accumulation and release of biomass and nutrients, which confirms the importance of cover crops in the early years of SPD. The crop systems in which maize was sown $\left(\mathrm{S}_{4}\right.$ and $\left.\mathrm{S}_{5}\right)$ showed similar yields. However, when maize was sown under SPD, there was a reduction in yield compared to SPC. These results suggest that maize should not be sown in soils under recently implemented SPD. For upland rice, the soil disturbance caused by conventional tillage favored grain yield due to the incorporation of plant residues increasing soil aeration (root growth), which favored the mineralization of organic matter and increased the available nitrogen $\left(\mathrm{NO}_{3}{ }^{-}\right.$and $\mathrm{NH}_{4}^{+}$). 

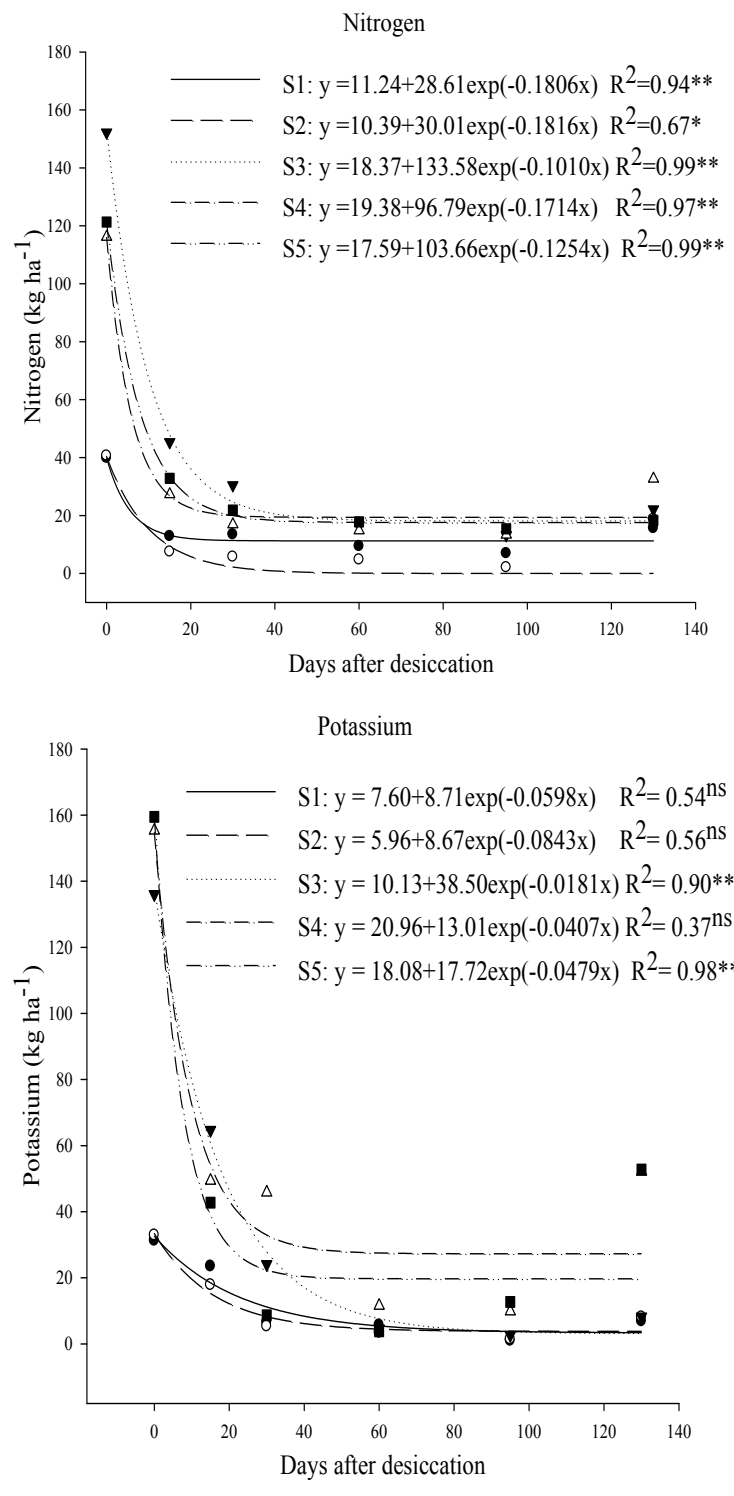

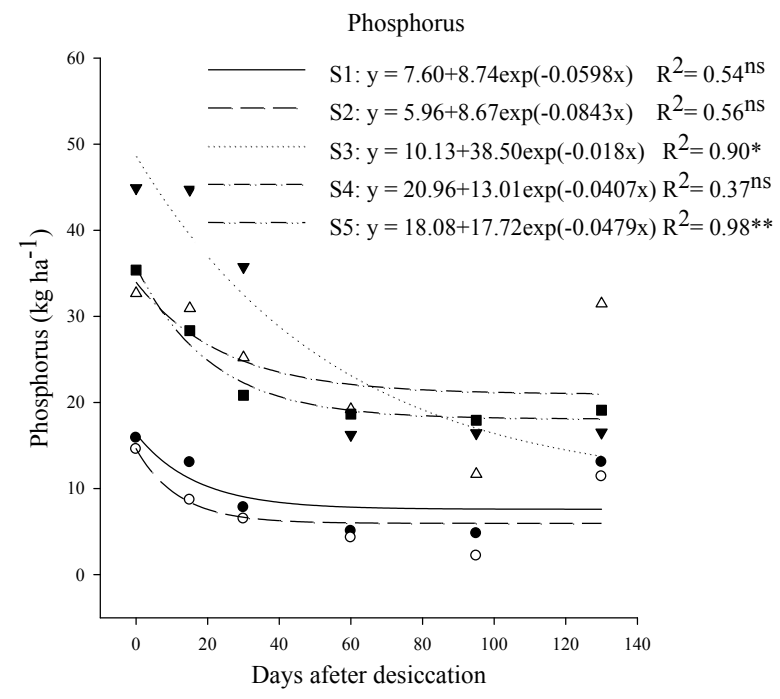

Calcium

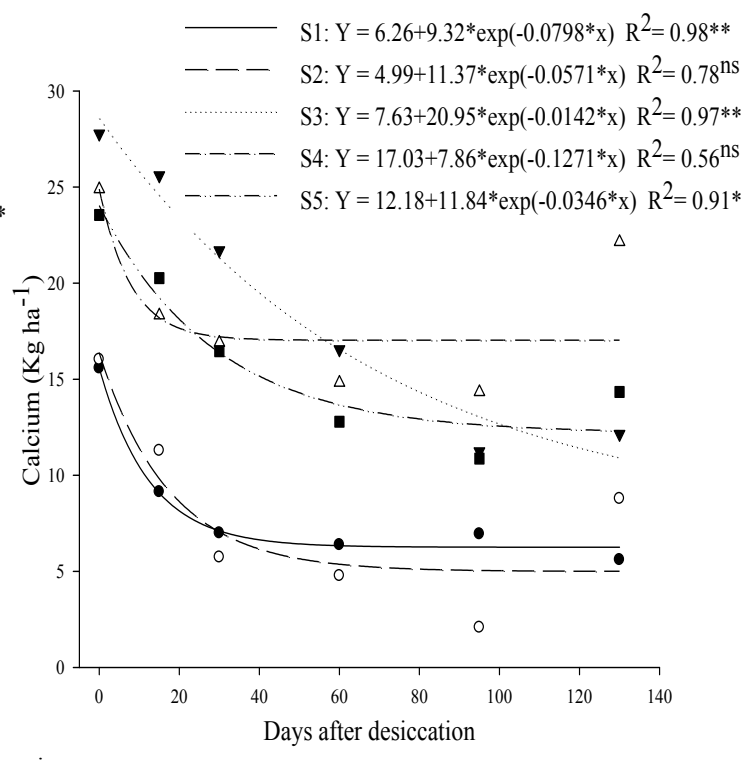

Magnesium

$\mathrm{S} 1=\mathrm{Y}=1.80+13.55 * \exp (-0.0515 * \mathrm{x}) \mathrm{R}^{2}=0.94 * *$

$\mathrm{S} 2=\mathrm{Y}=0.81+14.07 * \exp (-0.0355 * \mathrm{x}) \mathrm{R}^{2}=0.99 * *$

$\mathrm{S} 3=\mathrm{Y}=2.69+0.67 * \exp (-0.3686 * \mathrm{x}) \mathrm{R}^{2}=0.99 * *$

$\mathrm{S} 3=\mathrm{Y}=2.69+0.67 * \exp \left(-0.3686^{*} \mathrm{x}\right) \mathrm{R}^{2}=0.99 * *$
$\mathrm{~S} 4=\mathrm{Y}=9.75+13.80^{*} \exp \left(-0.1913^{*} \mathrm{x}\right) \mathrm{R}^{2}=0.83^{\mathrm{ns}}$

- - $-\mathrm{S} 5=\mathrm{Y}=7.75+14.12 * \exp (-0.0665 * \mathrm{x}) \mathrm{R}^{2}=0.76^{\mathrm{ns}}$

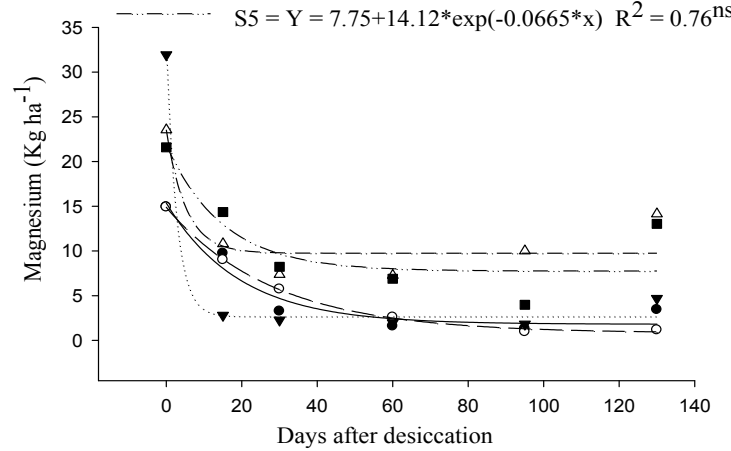

Figure 3. Accumulation and release of nutrients in the biomass of cover crops used in no-tillage crop systems during the crop season. 
Table 5. Grain yields of soybeans, maize and upland rice $\left(\mathrm{kg} \mathrm{ha}^{-1}\right)$ under two soil management systems and five crop systems, Crop year 2011/12, Bom Jesus, PI.

\begin{tabular}{|c|c|c|c|}
\hline \multirow{2}{*}{ Crop systems } & \multicolumn{3}{|c|}{ Soil management systems ${ }^{(1)}$} \\
\hline & SPD & & $\mathrm{SPC}$ \\
\hline \multicolumn{4}{|c|}{ Soybean } \\
\hline $\mathrm{S} 1$ & $3468 \mathrm{Bb}$ & & $4076 \mathrm{Aa}$ \\
\hline S3 & $3876 \mathrm{Ba}$ & & $4185 \mathrm{Aa}$ \\
\hline \multicolumn{4}{|c|}{ Upland rice } \\
\hline S2 & $2000 \mathrm{~B}$ & & $2500 \mathrm{~A}$ \\
\hline \multicolumn{4}{|c|}{ Maize } \\
\hline S4 & $6857 \mathrm{Ba}$ & & $8095 \mathrm{Aa}$ \\
\hline S5 & $6972 \mathrm{Ba}$ & & $8000 \mathrm{Aa}$ \\
\hline CV $(\%)$ & \multicolumn{3}{|c|}{2.48} \\
\hline DMS & \multicolumn{3}{|c|}{73.04} \\
\hline
\end{tabular}

Means followed by the same letters in columns bounded by the upper and lower lines do not differ based on Tukey's test at $5 \%$ probability ${ }^{(1)}$. SPD: no-tillage and SPC: conventional tillage.

\section{CONCLUSIONS}

Crop systems including $U$. ruziziensis and $P$. glaucum overseeded on soybeans and $U$. ruziziensis intercropped with maize showed higher biomass and nutrient cycling. Nitrogen and potassium were accumulated in higher amounts in biomass. Nitrogen showed the highest rates of release, followed by magnesium, potassium, phosphorus and calcium. The no-tillage system reduced the yield of annual crops. U. ruziziensis cultivated during the second season showed the potential to mitigate the reduction in the yield of soybeans sown under recently implemented no-tillage soil management.

\section{ACKNOWLEDGEMENTS}

The authors are grateful to CAPES for the granting of a master's scholarship to the second author. Thanks to $\mathrm{CNPq}$ for financial assistance (Universal 2010, Proj. ${ }^{\circ}$ n. 477208/2010-0) and the "Productivity in Reserach - Pq2" grant received by the first and third authors. Thanks to Sementes Celeiro for technical assistance.

\section{REFERENCES}

AITA, C.; GIACOMINI, S. J. Decomposição e liberação de nitrogênio de resíduos culturais de plantas de cobertura de solo solteiras e consorciadas. Revista Brasileira de Ciência do Solo, Viçosa, v. 27, n. 4, p. 601-612, 2003.

BERTIN, E. G. et al.. Plantas de cobertura em pré-safra ao milho em plantio direto. Acta
Scientiarum Agronomy, Maringá, v. 27, n. 3, p. 379-386, 2005.

BORGHI, C. A. et al. Desenvolvimento da cultura do milho em consorciação com Brachiaria brizantha em sistema plantio direto. Energia na Agricultura, Botucatu, v. 21, n. 3, p. 19-33, 2006.

BURLE, M. L. et al. Caracterização das espécies de adubo verde. In: CARVALHO, A. M.; AMABILE, R. F. (Eds.). Cerrado: adubação verde. Brasília: Embrapa Cerrados, 2006. v. 1, cap. 3, p. 71-142.

CARNEIRO, M. A. C. et al. Atributos físicos, químicos e biológicos de solo de Cerrado sob diferentes sistemas de uso e manejo. Revista Brasileira de Ciência do Solo, Viçosa, v. 33, n. 1, p. 147-157, 2009.

CARVALHO, A.M. et al. Cover plants with potential use for crop-livestock integrated systems in the Cerrado region. Pesquisa Agropecuária Brasileira, Brasília, v. 46, n. 10, p. 1200-1205, 2011.

\section{COMPANHIA NACIONAL DE ABASTECIMENTO - CONAB. Quinto Levantamento da Produção de Grãos - Safra 2013/14. Disponível em: <http:// www.conab.gov.br>. Acesso em: 14 de fev. 2014.}

CRUSCIOL, C. A. C. et al. Persistência de palhada e liberação de nutrientes do nabo forrageiro no plantio direto. Pesquisa Agropecuária Brasileira, Brasília, v. 40, n. 2, p. 161-168, 2005.

CRUSCIOL, C. A. C.; SORATTO, R. P. Nutrição e produtividade do amendoim em sucessão ao cultivo 
de plantas de cobertura no sistema plantio direto. Pesquisa Agropecuária Brasileira, Brasília, v. 42, n. 11, p. 1553-1560, 2007.

GIACOMINI, S. J. et al. Liberação de fósforo e potássio durante a decomposição de resíduos culturais em plantio direto. Pesquisa Agropecuária Brasileira, Brasília, v. 38, n. 9, p. 1097-1104, 2003.

KLUTHCOUSKI, J. et al. Manejo do solo e o rendimento de soja, milho, feijão e arroz em plantio direto. Scientia Agricola, Piracicaba, v. 57, n. 1, p. 97-104, 2000.

LARA CABEZAS, W. R. L. et al. Influência da cultura antecessora e da adubação nitrogenada na produtividade de milho em sistema plantio direto e solo preparado. Ciência Rural, Santa Maria, v. 34, n. 4, p. 1005-1013, 2004.

MORETI, D. et al. Atributos químicos de um Latossolo Vermelho sob diferentes sistemas de preparo, adubações e plantas de cobertura. Revista Brasileira de Ciência do Solo, Viçosa, v. 31, n. 1, p. 167-175, 2007.

NOGUEIRA, A. R. A et al. Tecido vegetal. In: NOGUEIRA, A. R. A. et al. (Eds.). Manual de laboratórios: solo, água, nutrição vegetal, nutrição animal e alimentos. São Carlos: Embrapa Pecuária Sudoeste, 2005. 1 ed., cap. 4, p. 145-199.

PACHECO, L. P. et al. Ciclagem de nutrientes por plantas de cobertura e produtividade de soja e arroz em plantio direto. Pesquisa Agropecuária Brasileira, Brasília, v. 48, n. 9, p. 1228-1236, 2013 a.

PACHECO, L. P. et al. Desempenho de plantas de cobertura em sobressemeadura na cultura da soja. Pesquisa Agropecuária Brasileira, Brasília, v. 43, n. 7, p. 815-823, 2008.

PACHECO, L. P. et al. Produção de fitomassa e acúmulo de nutrientes por plantas de cobertura no cerrado piauiense. Bragantia, Campinas, v. 72, n. 3, p. 237-246, 2013 b.

PACHECO, L. P. et al. Produção de fitomassa e acúmulo e liberação de nutrientes por plantas de cobertura na safrinha. Pesquisa Agropecuária Brasileira, Brasília, v. 46, n. 1, p. 17-25, 2011.

PACHECO, L. P. et al. Profundidade de semeadura e crescimento inicial de espécies forrageiras utilizadas para cobertura do solo. Ciência e Agrotecnologia, Lavras, v. 34, n. 5, p. 1211-1218, 2010.

PACHECO, L. P. et al. Sobressemeadura da soja como técnica para supressão da emergência de plantas daninhas. Planta Daninha, Viçosa, v. 27, n. 3, p. 455-463, 2009.

PAUL, E. A.; CLARK, F. E. Soil microbiology and chemistry. 1. ed. San Diego: Academic Press, 1989. $275 \mathrm{p}$.

PIRES, F. R. et al. Manejo de plantas de cobertura antecessoras à cultura da soja em plantio direto. Revista Ceres, Viçosa, v. 55, n. 1, p. 94-101, 2008.

SODRE FILHO, J. et al. Fitomassa e cobertura do solo de culturas de sucessão ao milho na região do cerrado. Pesquisa Agropecuária Brasileira, Brasília, v. 39, n. 2, p. 327-334, 2004.

TORRES, J. L. R. et al. Produção de fitomassa por plantas de cobertura e mineralização de seus resíduos em plantio direto. Pesquisa Agropecuária Brasileira, Brasília, v. 43, n. 3, p. 421-428, 2008.

VAN SOEST, P. J. et al. Methods for Dietary fiber, neutral detergent fiber, and nonstarch polysaccharides in relation to animal nutrition. Journal of Dairy Science, Salt Lake City, v. 74, n. 10, p. 3586-3597, 1991.

WIEDER, R. K.; LANG, G. E. A critique of the analytical methods used in examining decomposition data obtained from litter bags. Ecology, Washington, v. 63, n. 6, p. 1636-1642, 1982. 